\title{
From Russianisation to Legalisation: Russia and the Question of Successor State to the Soviet Union
}

\author{
Emmanuel Oladipo Ojo ${ }^{\mathrm{a}, \mathrm{b}}$ * \\ a Ekiti State University \\ Ado-Ekiti, Ekiti State, Nigeria \\ ${ }^{b}$ Siberian Federal University \\ 79 Svobodny, Krasnoyarsk, 660041, Russia
}

Received 09.10.2017, received in revised form 24.11.2017, accepted 08.12.2017

\begin{abstract}
For some supposedly obvious - or oblivious - reasons, Russia is almost always referred to as the successor State to the defunct Union of Soviet Socialist Republics, USSR, just as the USSR itself was the successor to Tsarist Russia. Following the February Revolution and the 15 March 1917 abdication of Emperor Nicolas II, the three-century old Romanov dynasty was thrown off the throne. Also in the same manner, following the October Revolution and the overthrow of the Alexander Kerensky-led Provisional Government, four Socialist Republics were established on the territory of the defunct Russian Empire - these were the Russian and Transcaucasian Soviet Federated Socialist Republics and the Ukrainian and Belarusian Soviet Socialist Republics. On 28 December 1922, these constituent Republics established the USSR and additional union republics were later established. The USSR lasted seven decades and collapsed in 1991 resulting in the dismemberment of the 15-member geo-polity. For some probably fairly clear historical and demographical factors - but oftentimes 'traditional supposition' - the Russian Federation, established on 25 December 1991, has often been regarded as the successor State to the USSR. This paper presents a two-fold contention: one, that the Soviet Union had long been 'Russianised' before its dissolution and that the 'legal' garb with which Russia was decked in 1991 was a mere semantics and change of nomenclature: 'Russianisation' to 'legalisation'; and two, that the description of Russia as successor State to the Soviet Union, though popular, is a misnomer and concludes that Russia is a 'continuing State' and not a 'successor State' to the Soviet Union.
\end{abstract}

Keywords: Russia, Russian Empire, USSR, Russianisation, revolution, population, republics.

DOI: 10.17516/1997-1370-0185.

Research area: history.

\section{Introduction}

\section{and Conceptual Discourse}

Comrades, this day marks a turning point in the history of the Soviet power. It places a landmark between the old period, now past, when the Soviet republics, although they acted in common, yet each followed its own path and was concerned primarily with its own preservation, and the new period, already begun, when an end is being put to the isolated existence of the Soviet republics, when the republics are being

(c) Siberian Federal University. All rights reserved

* Corresponding author E-mail address: eodzho@sfu-kras.ru; emmanuel-oladipo.ojo@eksu.edu.ng 
united into a single union state for a successful struggle against economic ruin, and when the Soviet power is concerned not only with its preservation, but with developing into an important international force, capable of influencing the international situation and of modifying it in the interests of the working people ... all the Soviet republics must be pooled; all the financial and economic potentialities of the republics must be concentrated on the task of restoring our basic industries. Hence, the necessity for uniting the Soviet republics into a single union state. Today is the day of the union of our republics into a single state for the purpose of pooling all our forces for the restoration of our economy. ${ }^{1}$

With the above speech by Vladimir Lenin to the First Congress of Soviets of the USSR in Moscow on 30 December 1922; the Union of Soviet Socialist Republics, a geo-political and economic entity, which was to make lasting impact on world history, was formed. The dire and explosive circumstances that led to the fall of the Russian Empire and the Romanov dynasty which ruled Russia for more than three centuries have attracted extensive scholarly attention and, therefore, need not be repeated here. ${ }^{2}$ Suffice it to state that a combination of internal and external factors, particularly wide spread dissatisfaction and frustration with autocracy $^{3}$ and hunger at home as well as series of catastrophic failures abroad, most especially Russia's poor showing and humiliation in the First World War (then ongoing) ${ }^{4}-$ led to the demand for 'peace, land and bread's which eventually led to the abdication of Nicolas II described as "a complex, contradictory man and ruler ... notorious for saying one thing and doing another". ${ }^{6}$ Following widespread revolts and pervasive chaos, the Duma, Russia's representative assembly, resolved that "in view of the grave situation of internal disorder, caused by measures taken by the old government, the
Interim Committee of Members of the State Duma has found itself obliged to take into its own hands the restoration of state and public order". ${ }^{7}$ Bereft of popular support and military backing, Nicolas had to abdicate and in his abdication note, he wrote, inter alia, "At this moment, a moment so decisive for the existence of Russia, Our conscience bids Us to facilitate the closest union of Our subjects and the organization of all their forces for the speedy attainment of victory. For that reason We think it right - and the Imperial Duma shares our view - to abdicate the crown of the Russian state and resign the supreme power"8. The abdication of Nicolas left Russia without a Tsar for the first time in 300 years. The subsequent emergence of the Provisional Government and its immediate recognition by the United States and later Great Britain, France and Italy marked the end of the Russian Empire and the Romanov dynasty. On 17 July 1918, Nicolas and his family members, their doctor, servants and one of their pet dogs were taken down into a cellar and executed by the Commander Yurovsky-led execution squad. ${ }^{9}$

The commitment of the Provisional Government to continue to fight in the First World War, unabated losses at virtually all fronts and the fear of a German advance on Moscow made the Provisional Government unpopular. A series of fatal events occurred in quick succession and eventually led to the 7 November 1917 Bolshevik Revolution wherein forces loyal to Vladimir Ilyich Lenin overthrew the Provisional Government. An alliance of anti-Bolshevik White Army forces tried to counter but the Bolshevik Red Army defeated them in the Russian Civil War. Thus, in 1922, the Communist Party formed the Union of Soviet Socialist Republics, a one-party, four-member republic that later grew into a 15member republic superpower until its dissolution in 1991. 


\section{Russia and the Question of Succession to the Soviet Union}

The theory of state succession in international relations, which has its root in the $19^{\text {th }}$ century diplomacy, refers to a situation wherein one state takes the place of another and undertakes a permanent exercise of its sovereign territorial rights or powers. ${ }^{10}$ In other words, succession of state occurs when one state ceases to exist or loses control over part of its territory and another state comes into existence or assumes control over the territory lost by the first state. There are two categories of succession - universal or partial. The former occurs when any of the following takes place: one, total or complete absorption, annexation or subjugation of one state by another. Although still a subject of tense international disputation, the February 2014 occupation and annexation of Crimea by Russia may well fall into this category. ${ }^{11}$ Two, the division of a hitherto united and possibly coercive state into several internationally recognisable or recognised states. This is the category to which the disintegration of the Soviet Union - the focus of this paper-belongs. The collapse of Socialist Federal Republic of Yugoslavia in the early 1990s may also be said to belong to this category. ${ }^{12}$ Three, when a state is broken up and divided among several previously existing states as was the case with the division of Poland between Russia, Prussia and Austria. ${ }^{13}$ On the other hand, partial succession occurs when a state acquires a portion of the territory of another through cession or conquest; when a new state is formed as a result of a successful revolt or declaration of independence; when a fully fledged sovereign state losses a proportion of its external sovereignty or independence through incorporation into a federal union or places itself under the protectorate of a stronger power or when this is reversed and a state under suzerainty or protectorate or member of a federal union transform into full sovereign state. ${ }^{14}$
Article 2(b) of the Vienna Convention on Succession of States in Respect of Treaties defines succession of states as "replacement of one state by another in the responsibility for the international relations of territory" and Article 2(d) defines successor state as "the state which has replaced [not a state that continues as] another state". ${ }^{15}$ This is the sense in which this study conceives the term 'successor state'. A number of scholars and commentators have referred to the Russian Federation as the successor state to the Soviet Union. For example Koziński Cardinal described Russia as the "successor... of the USSR" ${ }^{\prime 16}$ while Patrick Dumberry referred to Russia as the "legal "continuator" of the USSR ${ }^{17}$ Also, former dissident and president of Lithuania, Uytautas Landsbergis, described the Russian Federation as "the successor state to the USSR"18. The present author feels that the description of Russia as the 'successor State' to the Soviet Union is a misnomer. Also, while Dumberry's description of Russia as the 'continuator' of the USSR may be in order; the legal status acquired by Russia in 1991 requires some qualification - it was a mere change of nomenclature: from 'Russianisation' to legalisation.

This study does not intend to veer into the age-long debate on 'Russification', which in sum, refers to some sort of cultural assimilation of non-Russians - that is the official and unofficial policies and tendencies of Imperial Russia and the Soviet Union (with respect to their national constituents and national minorities) aimed at perpetuating all-sector Russian dominance. ${ }^{19}$ Simply rendered, 'Russianisation' (an aspect of 'Russification'), in the context of this study, means making Russia the master or pivotal constituent of the Soviet Union. As shall be shown as the study progresses, some of the speeches by the leaders of the Soviet Union and their nativity buttress this point of view. Indeed, it would appear that 
$a b$ initio, the defunct Soviet Union was formed to contain Russia and to accommodate the other supposedly co-republics. This was probably why Stalin, himself a non-Russian, placed Russia in a pivotal position in the newly formed Soviet Union when he said, inter-alia:

But, comrades, today is not only a day for summing up, it is at the same time the day of triumph of the new Russia over the old Russia, the Russia that was the gendarme of Europe, the Russia that was the hangman of Asia. Today is the day of triumph of the new Russia, which has smashed the chains of national oppression, organised victory over capital, created the dictatorship of the proletariat, awakened the peoples of the East, inspires the workers of the West, transformed the Red Flag from a Party banner into a State banner, and rallied around that banner the peoples of the Soviet republics in order to unite them into a single state, the Union of Soviet Socialist Republics, the prototype of the future World Soviet Socialist Republic ${ }^{20}$.

Indeed, the composition of delegates to the first Congress of Soviets of the USSR which took place in Moscow on 30 December 1922 was an unambiguous pointer to the fact that the Soviet Union was going to be created for Russia but would accommodate the other republics. Of the 2,215 delegates, 1,727 (78\%) were from the Russian Soviet Federated Socialist Republic (RSFSR), 364 (16\%) from the Ukrainian SSR, 91 () from the Transcaucasia Federation and 33 from the Belorussian SSR. ${ }^{21}$ It must be conceded however that Russian was the demographical backbone of the Soviet Union. The table 1-2 below attests to this:

Table 1. From formation to dissolution: Population estimates of the Soviet Union per decade 1922-1991 (millions)

\begin{tabular}{lccccccccc} 
& 1922 & 1932 & 1942 & 1952 & 1962 & 1972 & 1982 & 1991 \\
\hline Russian SFRS (1922) & 87.7 & 100.4 & 112 & 105.7 & 122 & 131.4 & 139.8 & 148.6 \\
Ukrainian SSR (1922) & 26.2 & 29.9 & 32.4 & 37.7 & 43.6 & 47.8 & 50.3 & 52 \\
Uzbek SSR (1924) & & 5.3 & 6.7 & 6.6 & 9 & 12.5 & 16.5 & 20.9 \\
Belorussian SSR (1922) & 4.3 & 5.2 & 6 & 7.7 & 8.2 & 9.1 & 9.7 & 10.1 \\
Kazakh SSR (1936) & & & 6.2 & 7 & 10.8 & 13.7 & 15.1 & 16.5 \\
Azerbaijan SSR (1922) & $*$ & $*$ & $*$ & 3 & 4.1 & 5.3 & 6.3 & 7.2 \\
Georgian SSR (1922) & 2.4 & 3 & 3.5 & 3.6 & 4.8 & 4.8 & 5.6 & 4.8 \\
Tajik SS-R (1929) & & 1.2 & 1.4 & 1.6 & 2.1 & 3 & 4.1 & 5.4 \\
Moldavian SSR1940) & & & 2.4 & 2.4 & 3.1 & 3.5 & 4 & 3.7 \\
Kirghiz SSR(1936) & & & 1.5 & 1.7 & 2.3 & 3 & 3.7 & 4.4 \\
Lithuanian SSR(1940) & & & 2.6 & 2.5 & 2.8 & 3.2 & 3.4 & 3.7 \\
Turkmen SSR(1924) & & 1.1 & 1.2 & 1.2 & 1.6 & 2.2 & 2.9 & 3.7 \\
Armenian SSR(1922) & $*$ & $*$ & $*$ & 1.4 & 1.9 & 2.6 & 3.1 & 3.5 \\
\hline Latvian SSR(1940) & & & 2 & 1.9 & 2.1 & 2.4 & 2.5 & 2.6 \\
\hline Estonian SSR(1940) & & & $*$ & 1.1 & 1.2 & 1.3 & 1.4 & 1.5 \\
\hline
\end{tabular}

* Population estimates not available even though these Republics were already part of the Soviet Union. The dates in the first column indicate the year of membership of the Soviet Union.

Source: Compilation. See, among others, Lee Schwartz, "A History of Russian and Soviet Censuses" in Clem S. Ralph (ed.), Research Guide to the Russian and Soviet Censuses, Ithaca: Cornel University Press, 2016, pp. 48- 69; "USSR: Demographic Trends and Ethnic Balance in the Non-Russian Republics", A Research Paper by CIA, Historical Review Program, 1999; Anderson A. Barbara \& Silver D. Brian, "Growth and Diversity of the Population of the Soviet Union", Annals of the American Academy of Political Science and Social Science, 510, July 1990, pp. 155-177; and Frank Lorimer, "The Population of the Soviet Union: History and Prospects", Economic, Financial and Transit Department, Geneva: League of Nations, 1946. 
From the above tables, Russia's 'demographic tyranny' and domination of the Soviet Union, akin to that of Northern Nigeria in the lopsided Federation of Nigeria, is obvious. This also probably explains why only two of the eight leaders of the Soviet Union were non-Russians. ${ }^{22}$ However, in a rare twist of fate, divine providence or mere coincidence, the tenures of the two nonRussian leaders totalled 47 years leaving only 21 years to the Union's six Russian leaders.

A close examination of the history of the Soviet Union would reveal that over and again its non-Russian members expressed grave resentment and reservations about the 'Russianisation' of the Soviet Union. ${ }^{23}$ As Andreas has pointed out, this constituted an unresolved 'national question' which assailed the Soviet Union until its disintegration in 1991. But, being a 'union' by threat of force, the strict and closed command structure and leadership style of the Union prevented the 'national question' from posing any notable or dangerous threat unlike in Nigeria, where the 'national question' ('Northernisation' of Nigeria) has consistently remained a volatile and unresolved national debacle. ${ }^{24}$ Geographically and demographically, Russia constituted more than $50 \%$ of the Soviet Union while Ukraine, the second largest republic, constituted just about $19 \%$ of the population and $2 \%$ of the land mass. It is therefore not surprising that giant Russia became the de facto dominator of and decider for the Lilliputian republics. Thus, the "Russians became the older and the other republics the younger brothers". ${ }^{25}$ The following quotation, though fairly lengthy, summarises the 'Russianisation' of the Soviet Union

One of the dangers threatening this unity was the old feeling of Great-Russian chauvinism inherited from the past Czarist regime. As long as J. V. Stalin was in

Table 2. Total population estimates of the Soviet Union (millions) per decade and percentage (\%) share per Republic (1922-1991)

\begin{tabular}{|c|c|c|c|c|c|c|c|c|}
\hline & $\begin{array}{c}1922 \\
(120.6) \\
\end{array}$ & $\begin{array}{c}1932 \\
(146.1) \\
\end{array}$ & $\begin{array}{c}1942 \\
(177.9) \\
\end{array}$ & $\begin{array}{c}1952 \\
(185.1) \\
\end{array}$ & $\begin{array}{l}1962 \\
(219) \\
\end{array}$ & $\begin{array}{c}1972 \\
(245.8)\end{array}$ & $\begin{array}{c}1982 \\
(268.4) \\
\end{array}$ & $\begin{array}{c}1991 \\
(288.6) \\
\end{array}$ \\
\hline Russian SFRS & 73 & 69 & 63 & 57 & 56 & 53 & 52 & 51 \\
\hline Ukrainian SSR & 22 & 20 & 18 & 20 & 20 & 19 & 19 & 18 \\
\hline Uzbek SSR & & 4 & 4 & 4 & 4 & 5 & 6 & 7 \\
\hline Belorussian SSR & 4 & 4 & 3 & 4 & 4 & 4 & 4 & 3 \\
\hline Kazakh SSR & & & 3 & 4 & 5 & 6 & 6 & 6 \\
\hline Azerbaijan SSR & & & & 2 & 2 & 2 & 2 & 2 \\
\hline Georgian SSR & 2 & 2 & 2 & 2 & 2 & 2 & 2 & 2 \\
\hline Tajik SSR & & 0.8 & 0.7 & 0.8 & 0,9 & 1 & 2 & 2 \\
\hline Moldavian SSR & & & 1 & 1 & 1 & 1 & 1 & 1 \\
\hline Kirghiz SSR & & & 0.8 & 0,9 & 1 & 1 & 1 & 2 \\
\hline Lithuanian SSR & & & 1 & 1 & 1 & 1 & 1 & 1 \\
\hline Turkmen SSR & & 0.7 & 0.6 & 0.6 & 0.7 & 0.9 & 1 & 1 \\
\hline Armenian SSR & & & & 0.8 & 0.8 & 1 & 1 & 1 \\
\hline Latvia & & & 1 & 1 & 1 & 1 & 1 & 0.9 \\
\hline Estonia & & & & 0.6 & 0.5 & 0.5 & 0.5 & 0.5 \\
\hline
\end{tabular}

*For a comprehensive examination of the factors responsible for certain vagaries in the population of member states of the USSR, see The Proceedings of the International Conference on "Crimes of the Communist Regimes: An Assessment" held on 24-25 February 2010 in the Senate Building, Prague, Czech Republic. 
the leadership of the Soviet party and state in the Soviet Union, the various manifestations of Great-Russian chauvinism were not permitted, on the contrary they were fought with fierceness and consistency. Stalin emphasized that "We may lose all we won then (reference is to the days of the October Revolution) if we fail to arm ourselves against this new chauvinism, I repeat it, Great-Russian chauvinism, which is on the offensive and is spreading, gradually penetrating the minds of our militants and corrupting them slowly It is precisely this danger, comrades, which we must wipe out altogether. Otherwise... we are threatened with the prospect of severing the links between these peoples and the Russian proletariat ... After Stalin died, the Khrushchevite revisionists ... began to undermine everything positive that had been achieved in the implementation of the national policy. The road followed by Khrushchev and by his disciples later meant the destruction of the great work of Lenin and Stalin for the correct Marxist-Leninist settlement of the national question in the conditions of a multinational state. The proportional development between the republics was interrupted and the discrimination of the smaller, peripheral republics and nations, particularly of the non-Russian ones, began gradually to give way bit by bit to the old Great-Russian chauvinism ... It is evident that the Russians are the predominant majority in the central organs of the party, in the state, in the Presidium of the Supreme Soviet, in the Council of Ministers. The same applies to the majority of state committees, the competences of which extend both to the centre and the republics. ${ }^{26}$

On a number of occasions, the above imbalance led to tension and protests by the nonRussian members of the Soviet Union. A few instances will suffice. In 1976 some Georgians protested against what they termed the deliberate promotion and advancement of 'Russianisation'. Likewise, by the middle of April 1978, a group of demonstrators took to the streets of Tbilisi against the efforts to weaken the status of the Georgian language. Also, in July 1983, a demonstration with nationalist tendencies again broke out in Georgia. Indeed, on many occasions, the Tajik, Kirgiz, Azerbaijani and Uzbek advocated the need for some semblance of equality and carried out acts which expressed the need for national desires and interest for a more advanced and equitable socio-economic and cultural development. On 22 December 1980, protests and demonstrations broke out in Estonia against the policy of 'Russianisation'. Prior to that, on 1 and 3 October of the same year, a large number of youths had organized mass demonstrations with more than 5,000 people taking to the streets shouting slogans like "Freedom to Estonia", "Russians, get out of Estonia!'. Similar protests again took place on 27 and 30 March 1981 in Tbilisi, with students and intellectuals demonstrating for 5 hours in front of the building of the local Supreme Soviet. ${ }^{27}$

In spite of the fact that protest, under any guise, was an extremely risky endeavour in the Soviet Union; that the above incidents occurred was a mark and evidence of the serious exceptions some constituents of the Soviet Union took to the 'national question'. Indeed, according to a United States' classified document (released to the public in February 1994) "throughout Soviet history...public political activity, such as protests and demonstrations [was] considered illegal and politically impermissible. Under Andropov, no less than his predecessors, any public protester takes a significant risk, no matter how peaceful the act, and at the very least, must expect harsh treatment...including immediate arrest...loss of pay or jobs, longer prison term, forced labor or confinement in mental institutions". ${ }^{28}$. The above notwithstanding, there were probably more than 280 cases of civil unrest in the Soviet Union between 1970 and 1982 some of which must have bordered on the resentment and reservations discussed above. ${ }^{29}$ Thus, viewed from any perspective, Russia was not just a primus inter pares in the Soviet Union; she was 
the pivot around which the Soviet superstructure revolved.

Although, Zvorykin was completely silent on this in his rather lengthy eulogy of the Soviet Union's cultural policy; ${ }^{30}$ some Soviet leaders consciously encouraged Russians to 'colonise' the non-Russian constituents of the Soviet Union by substantially heavy immigration of Russians to those places and the 'imposition' of Russian language. For example, the heavy influx of Russians into Ukraine ensured that by 1989 the over 11.3 million Russians in Ukraine constituted more than 22 percent of Ukraine's population. ${ }^{31}$ Thus, Russians became "a privileged people. While the non-Russians were pressured to learn and use Russian, very few of the Russian, or Russian-speaking migrants, bothered to learn the languages of non-Russian nationalities, even if they lived among them"32. Thus, long before its dissolution, Russia was the princely constituent of the Soviet Union. Viewed in this context, it is not surprising that Russia is generally described as 'successor of the Soviet Union'.

Markedonov's description of Russia as "the legal successor of the Soviet Union" ${ }^{33}$ calls for a few remarks. Although, Markedonov did not explicitly define the context within which he used the term 'legal'; he probably used it to mean 'authority derived from or founded on law or established rules'. Dumberry's description of Russia as the 'legal "continuator" of the USSR' was also probably based in the same perception and interpretation of the term (legal).

As we are going to show presently, certain agreements and declarations legitimised and legalised Russia's ascendancy to the 'throne of the Soviet Union' following the dissolution of the latter in 1991. However, given the fact that Russia was almost synonymous with the Soviet Union before 1991; for all intents and purposes, the legitimisation or legalisation was a mere semantics and change of nomenclature: from
'Russianisation' to legalisation. Indeed, one cannot but agree with Pokrovskaya's description of the Soviet Union as a Russian Empire which fell in 1991 just as its predecessor-empire fell in 1917. According to her, "as in 1917, the Russian Empire died; in 1991, the restored empire died a second time...there was an a priori application of the ethnonym 'Russian' to practically everything connected with the USSR". ${ }^{34}$ Indeed, in a report on the dissolution of the Soviet Union, Bohlen referred to Russia as 'the Soviet Union'. ${ }^{35} \mathrm{Be}$ that as it may, let us proceed to examine the background to Russia's legal status as the 'continuator' of the Soviet Union.

\section{The Belavezha Accords and Alma-Ata Declaration}

On 8 December 1991, leaders of three of the 15 Soviet Republics, Russian President Boris N. Yeltsin, Ukrainian President Leonid M. Kravchuk and the Belarusian leader Stanislav Shushkevich, signed a declaration known as the Belavezha Accords. The preamble to the Accords declared that "We, the Republic of Belarus, the Russian Federation (RSFSR), and Ukraine, as founding states of the Union of Soviet Socialist Republics, having signed the 1922 Union Treaty, hereafter called the Supreme Contracting Parties, state that the Union of SSR as a subject of international law and geopolitical reality ends its existence". ${ }^{36}$ The three leaders thereafter established the Commonwealth of Independent States, CIS, a loose confederation of former Soviet states in place of the Soviet Union. According to Article 14 of the Accords "the activities of the former Union of SSR agencies on the territory of the Commonwealth memberstates now ceases". ${ }^{37}$ On 21 December, the leaders of eight additional Soviet Republics - Armenia, Azerbaijan, Kazakhstan, Kyrgyzstan, Moldova, Turkmenistan, Tajikistan, and Uzbekistan joined the new Commonwealth of Independent States 
(CIS), thus bringing the number of participating countries to 11. On 25 December, Mikhail Gorbachev resigned as the President of the Soviet Union on 'considerations of principle' and turned control of the Kremlin and the remaining powers of his office over to the office of the president of Russia, Boris Yeltsin, thus accepting the termination of the Soviet Federal Government and the dissolution of the Soviet Union.

Alexander Salenko has queried the morality and legality of the Belavezha Accords and the 'unilateral' decision of three member states to decide for a 15-member union. According to him, the Congress of People's Deputies of the USSR had on 27 December 1990 adopted the Law of the USSR "Concerning national voting (concerning the Referendum of the USSR)". He pointed out that a Referendum on the issue of the preservation of the USSR as a federation of equal republics was held on 17 March 1991 with the sole question "do you consider necessary the preservation of the Union of Soviet Socialist Republics as a renewed federation of equal sovereign republics in which the rights and freedom of an individual of any nationality will be fully guaranteed?". According to Salenko, the result of the Referendum showed that "113 512812 people voted for the preservation of the USSR (i.e. $77.85 \%$ of participating voters); while 32303977 people voted against (i.e. 22.15 $\%$ of participating voters). In total 148574606 voters took part in the referendum, representing a very considerable turnout of $80.03 \%$. At the time of the referendum the total number of registered voters in the USSR was 185647355 people, i.e. 37072749 Soviet voters did not participate in the voting". ${ }^{38}$ Salenko concludes that

the agreement of the three leaders was illegal with regard to the destiny of the whole state. De jure each republic could raise a question about its secession from the USSR; however, only by the will of all union republics and all citizens could the termination of the existence of the common union state be decided... the republics cannot decide questions concerning the rights and interests of other republics. From this point of view the statement containing in (Belavezha) Accord that 'the USSR as the subject of international law and geopolitical reality ceased to exist' ... has no validity and legal effect. ${ }^{39}$

However, the above submission requires some considerations and qualifications. In the first place, while it remains true that plebiscites could serve as mirror to measure and guard the aspirations and intentions of a people; sometimes, just as in general elections, plebiscites are nothing more than the expression of the wishes and aspirations of the political class. Second, only nine of the Soviet Republics - Russia, Ukraine, Byelorussia, Uzbek, Kazakh, Azerbaijan, Kirghiz, Tajik and Turkmen - participated in the referendum while six - Lithuania, Latvia, Estonia, Armenia, Georgia and Moldova boycotted it. While these republics may not have paraded large populations like Russia (148.6 m) and Ukraine (52 $\mathrm{m}$ ); the fact that they boycotted the referendum was obviously a pointer to the fact that these republics wanted self determination. Indeed, as Newman has pointed out, the gravest problem that confronted the Soviet Union at this time "were the independence movements in a number of Soviet republics". ${ }^{40}$ Third, as Rutland has opined, the signatories to the Belavezha Accords "represented three of the four republics that had signed the document creating the Soviet Union back in 1922 - and that the fourth, the Transcaucasus Republic, had been dissolved in 1936. That seemed to give a legal basis to their actions". ${ }^{41}$ It could therefore be argued that the three republics merely untied the political nuptial cord they had tied some seven decades earlier and dismembered the geo-polity they had assembled.

However, these observations and approximations do not detract from the fact that 
whatever the status of the Belavezha Accord legal or illegal - it effectively dissolved the Soviet Union; although this may as well raise an important question: if the Belavezha Accord was illegal and the subsequent Alma-Ata Protocol that transferred the legal garb of the Soviet Union to Russia was based on it; then the superstructure (Russia) built on it (the Accord) must be illegal. That would make Russia as 'illegal successor' to the Soviet Union. Be that as it may, the reason advanced by the convener of the Belavezha Forest gathering, Stanislau Shushkevich, Chairman of the Supreme Soviet Republic of Belarus, supports the thesis of this study - that the Soviet Union had been 'Russianised' long before the event of 1991. According to Stanislau, as the 1991/92 winter season approached, his country and Ukraine had a common challenge that only Yeltsin, the Russian President, could solve - they had no oil and gas. ${ }^{42}$ According to Stanislau "our economy was in crisis, we could not pay for the supplies [of oil and gas] and had no-one to lend us the moneyso we wanted to ask Russia to help us out, so that we don't freeze that winter. That was the aim of our meeting" ${ }^{43}$ Irrespective of whether what was $a b$ initio intended as a 'hunting for concession' invitation eventually metamorphosed into the 'balkanization' of the Soviet Union; Stanislau's submission validates the 'Russianisation' of the Soviet Union thesis of this study.

Alma-Ata, capital of the former Kazakh Soviet Socialist Republic and independent Kazakhstan (up till 10 December 1997 when Astana became the capital) is famous for serving as venue for two important gatherings where historic declarations were made. The first, which is widely known in medical circles, was in September 1978 when the International Conference on Primary Health Care made the now famous 'Ten Declarations' wherein the World Health Organisation expressed the need for urgent action by all governments, all health and development workers, and the world community to protect and promote the health of all people. This was the first international declaration that underlined the importance of primary health care. ${ }^{44}$ The second declaration and the one with which this study is concerned, is the Alma-Ata Protocol of 21 December 1991 which concurred with the Belavezha Accords that provided for the extinction of the legal and geopolitical existence of the Soviet Union and the establishment of a Commonwealth of Independent States in its stead. The Alma-Ata Declaration, signed by 11 of the 15 former Soviet Republics ${ }^{45}$ held that "With the formation of the Commonwealth of Independent States the USSR ceases to exist". ${ }^{46}$ The Protocol expressed satisfaction with the status of the Republics of Byelorussia and Ukraine as sovereign independent states and members of the United Nations. Furthermore, Article 1 of the fifth declaration titled 'On UN Membership', decked Russia in the legal and political garb of the Soviet Union by declaring that "Member states of the commonwealth support Russia in taking over the U.S.S.R. membership in the U.N., including permanent membership in the Security Council and other international organizations". ${ }^{47}$ Consequently, on 24 December 1991, Ambassador Vorontsov, the Permanent Representative of Soviet Union to the United Nations, transmitted a letter from Yeltsin, President of the Russian Federation, to the fifth Secretary-General of the United Nations, Javier Pérez de Cuéllar, stating that:

The membership of the Union of Soviet Socialist Republics in the United Nations, including the Security Council and all other organs and organisations of the United Nations system, is being continued [emphasis mine] by the Russian Federation with the support of the countries of the Commonwealth of Independent States. In this connection, I request that the name 'Russian Federation' should be used in the United Nations in 
the place of the Union of Soviet Socialist Republics. The Russian Federation maintains full responsibility for all the rights and obligations of the USSR under the Charter of the United Nations, including the financial obligations. I request that you consider this letter as confirmation of the credentials to represent the Russian Federation in the United Nations organs for all the persons currently holding the credentials of representatives of the USSR in the United Nations ${ }^{48}$.

Consequently, the Russian Federation took over the Soviet Union's seat in the United Nations General Assembly, the Security Council, and all other organs and arms of the UN. The process of decking the Russian Federation in the legal and political garb of the defunct Soviet Union climaxed on 31 January 1992 when the President of Russia, Yeltsin, sat in the Russian Federation's seat in the Security Council. ${ }^{49}$ As stated earlier, the focus of this study is not the determination of the legality or otherwise of the transfer of the Soviet Union's paraphernalia of office to the Federation of Russia; ${ }^{50}$ rather it is show that the Soviet Union had long been 'Russianised' before 1991 and that Russia is a continuator and not a successor of the Soviet Union. As emphasised above, there was no ambiguity in Yeltsin's letter to the United Nations on what Russia wanted and properly was - continuator of the Soviet Union. This was why the officials of the defunct Soviet Union merely transmuted into Russian officials and representatives on the spot without being subjected to fresh documentation like the members of the Commonwealth of Independent States the successor States to the Soviet Union - who did comprehensive documentation including the submission of membership application letters and the consideration of same by the United Nations Committee on Admission of New Members before the respective General Assembly Resolutions that formally admitted them were passed. ${ }^{51}$ Indeed, several countries including Norway and France expressly stated that they considered the Russian Federation to be the 'continuing State of the USSR'. ${ }^{52}$ Moreover, the UK government declared that it recognised Russia as the 'continuing State of the Soviet Union'53. Switzerland, Germany, Belgium and the Netherlands also described the Russian Federation as the continuator of the USSR while Finland said that she accepted the "status of Russia as the continuation of [the] former USSR" while Sweden opined that "Russia is taking the place of the Soviet Union". ${ }^{4}$ From the above, it should be fairly clear that the status the Federation of Russia applied for and got was that of 'continuator' of the Soviet Union while the other Republics, properly construed, are the successor States to the Soviet Union.

\section{Conclusion}

This study presents a two-fold argument: first, that long before its disintegration in 1991, the Soviet Union had been 'Russianised'. The study points out that in addition to several other manifestations of the 'Russianisation' of the Soviet Union; only two of the Union's eight leaders were non-Russians. Indeed, nine of the Soviet Union's ten Permanent Representatives at the United Nations were Russians - only Andrey Gromyko (1946-48) was not. ${ }^{55}$ The study points out that in view of Russia's demographical preponderance in the Union; that the former almost became synonymous with the latter is not surprising. Of the 15 republics, Russia was by far the largest and the most populous - its territory of about 17.075 million square kilometres constituted roughly 76 $\%$ of the total of the Union's 22.4 million square kilometres while its population of 148 million translated into about $51 \%$ of the total population of the Soviet Union's 288.7 million. As Yehuda has pointed out, "if one takes into consideration that five of the fifteen republics of the former Soviet Union (Ukraine, Belarus and the three Baltic republics) with a combined population of 
70.1 million and a territory of 986,000 square kilometres were already members of the UN at the time of the Soviet Union dissolution, Russia's share in the population of 218.6 million of the remaining ten republics rises to almost $68 \%$ and its share of the territory...almost $80 \%$ \% ${ }^{56}$ Although it created a griming and simmering 'national question' in the Soviet Union; this geographical and demographical tyranny ensured the successful 'Russianisation' of the Union. Ukraine, the second largest republic of the USSR and the Commonwealth of Independent States, with approximately a third of Russia's population, had become a member of the United Nations since 1945. Thus, unlike in Yugoslavia where succession issues created pervasive crisis that informed the setting up of the Badinter Arbitration Committee, with no dissent or discord, the CIS members decked the Russian Federation in the political and legal garb of the erstwhile Soviet Union so that the officers and representatives of the Soviet Union merely transmuted into the officers and representatives of the Russian Federation on the spot without the procedural documentation which the other republics were called upon to do. ${ }^{57}$ This transmutation made Russia to become the 'continuator' or the 'continuing' State of the Soviet Union while the other republics became successor States to the Soviet Union.

V.I. Lenin, "The Formation of the Union of the Soviet Republics", Speech Delivered at the First Congress of Soviets of the USSR, 30 December 1922, p. 1.

2 See, for example, Robert Service, The Last of the Tsars: Nicolas II and the Russian Revolution, London: Macmillan, 2017; Dominic Lieven, Towards the Flame: Empire, War, and the End of Tsarist Russia, New York: Penguin Books, 2016; Alexander Robinowitch, The Bolsheviks Come To Power New York: Haymarket Books, 2009; Bernadotte Schmitt, The Russian Revolution, Oxford: Oxford University Press, 2008; Leon Trotsk, History of the Russian Revolution, Chicago: Haymarket Books, 2008; Jane Burbank et. al. (eds), Russian Empire: Space, People, Power, 1700-1930, Indiana University Press: 2007 and Franco Venturi, Roots of Revolution, New York: Alfred A. Knopf, 1960.

3 Part of the autocracy of the tsarism was probably the rather long titles of the Emperors. For example, Nicholas bore proud and sonorous titles: 'Nicholas II, by God's grace, Emperor and Autocrat of all the Russias, King of Poland, Grand Duke of Finland, Tsar of Moscow, Kiev, Vladimir, Novgorod, Kazan, Astrakhan, Siberia, the Tauric Chersonese, Georgia, Lord of Pskov, Grand Duke of Smolensk, Lithuania, Volhynia, Podolia, Prince of Esthonia, Livonia, Courland, and Semigallia, Samogitia, Bielostok, Karelia, Tver, Yougoria, Perm, Viatka... Lord and Grand Duke of Lower Novgorod, Chernigov, Riazan, Polotsk, Rostov, Yaroslav... Lord and Sovereign of the lands of Iberia . . . and the Provinces of Armenia. Sovereign of the Circassian and Mountaineer Princes... Lord of Turkestan, Heir of Norway, Duke of Schleswig-Holstein Oldenburg, etc. etc.' See Edmund Walsh, "The Fall of the Russian Empire: The End of the Monarchy", The Atlantic, February 1928 Issue, p. 10.

4 As a result of backward industrial development, Russia could not stand up to the might of more highly industrialised Germany. The hardships imposed on the civilian population and the troops through inadequate transport, defective equipment, scarcity of food and high prices, together with the inefficiency and corruption of the ruling class provoked widespread dissatisfaction.

5 Apparently, this was a catchy summary of Russia's three-pronged immediate need at that tumultuous period: The First World War was disastrous for Russia. By the end of 1916, about 5 million Russian soldiers were died, captured, maimed or missing. The army was poorly commanded, poorly supplied and poorly motivated. At home, men, horses and material were requisitioned for the war, and hunger became widespread. Due to shortages caused by the war, protests and food riots broke out in Petrograd and in other cities. In addition, the Russian peasant population, who lived and toiled on minuscule amounts of land, saw that rich landowners with large estates continued to thrive at the expense of the poor. In several of Lenin's speeches, he insisted that peace would mean an end to the war with its unprecedented casualties; bread would mean relief from ubiquitous hunger while land would mean the prospect of self-sufficiency for the peasant population. In the end, these promises were not kept, although Russia did withdraw from the First World War through the Treaty of BrestLitovsk with the Central Powers on 3 March 1918; a fatal civil war almost immediately replaced the Great War while food continued to be scarce, and the Bolsheviks eventually confiscated land and moved peasants onto collective farms. Be that as it may, 'peace, land and bread' was a timely propaganda and effective political stick to beat the Provisional Government. Robert Service, The Last of the Tsars: Nicolas II and the Russian Revolution, p. 1.

Carolyn Harris, "The Abdication of Nicholas II Left Russia Without a Czar for the First Time in 300 Years", Smithsonian Magazine, 13 March, 2017 retrieved from http://www.smithonianmag.com/history-abdication-nicolas-ii-left-russiawithout-tsar-first-time-300-years on 28 September 2017.

For a fuller text of Nicolas' 'Abdication Note', see The Atlantic, February 1928 Issue, pp. 5, 7 and 11.

9 Robert Service, The Last of the Tsars: Nicolas II and the Russian Revolution, p. 6. The execution was carried out in the presence of Pavel Medvedev, a member of the squad of soldiers guarding the royal family. For this (eye witness) account, see "The Execution of Tsar Nicolas II, 1918" retrieved from http://www.eyewitnesstohistor.com/nicolas.htm on 28 September 2017. 
10 Amos S. Hershey, "The Succession of States", American Journal of International Law, Vol. 5, No. 2, April 1911, p. 285.

11 At present, despite international opinion, Crimea has been integrated into the Russian Federation as the currency, tax, legal system, automobile license plates and passports are all operational under Russian jurisdiction while the blue, red and white Russian flag now flies above public buildings. Crimea became part of the Russian Empire in 1783/84 when the Crimean Khanate was annexed by Catherine the Great. See Lydia Tomkiw, "Russia-Ukraine Conflict: Two Years After Crimea Annexation", International Business Times, 19 March 2016 and "How Catherine the Great Annexed Crimea", Exploring History, 11 January 2016.

12 For a detailed analysis of the factors that led to the breakup of the former Yugoslavia, see David Anderson "The Collapse of Yugoslavia", Research Paper No. 14 1995-96, Parliamentary Research Service, 1995, pp. 1-26.

13 The Polish-Lithuanian Commonwealth was thrice partitioned between 1772 and 1795 . These partitions ended the existence of the state, resulting in the elimination of sovereign Poland for 123 years. The partitions were conducted by the Russian Empire, the Kingdom of Prussia and Habsburg, which divided up the Commonwealth lands among themselves progressively in the process of territorial seizures. The First Partition of Poland was decided on 5 August 1772. Two decades later, Russian and Prussian troops entered the Commonwealth again and the Second Partition was signed on 23 January 1793. Austria did not participate in the Second Partition. The Third Partition took place on 24 October 1795. With this partition, the Commonwealth ceased to exist. This elimination of the sovereign state of Poland was in effect until the end of the First World War when the Polish Republic was finally restored on 11 November 1918. See Anita Prażmowska, Poland. A Modern History London: I.B. Tauris, 2010.

14 Amos S. Hershey, "The Succession of States", p. 285.

15 Vienna Convention on Succession of States in Respect of Treaties, 1978, p. 3.

16 Koziński B. Cardinal, "Historical Determinants of the Contemporary Polish-Russian Relations: Geographical and Nationalistic (Ethnic) Dimension”, Young Scientist, No. 9(12), September 2014, pp. 191 and 193.

17 Patrick Dumberry, State Succession to International Responsibility, Boston: Martinus Nijhoff Publishers, 2007 , p. 324.

18 Uytautas Landsbergis, Speech at the Conference on "Crimes of the Communist Regimes", delivered on 25 February 2010. The Conference held on 24 and 25 February 2010 in the Senate Building, Prague, Czech Republic Prague. Conference Proceedings, p. 347.

19 For a detailed examination of this, see Theodore R. Weeks, "Russification/Sovietization", European History Online, 2010 retrieved from http://leg-ego.eu/en/threads/models-and-stereotypes/russification-soviettization on 10 October 2017 and Petr Dostàl and Hans Knippenberg, 'The "Russification" of Ethnic Minorities in the USSR', Eurasian Geography and Economics, May 2013, pp. 197-219.

20 "The Formation of the Union of the Soviet Republics", Speech Delivered at the First Congress of Soviets of the U.S.S.R, 30 December 1922, p. 1.

$21 \quad$ See Pravda, No. 298, 31 December 1922, p. 2.

22 Vladimir Lenin (Russian), 30 December 1922 - 21 January 1924; Joseph Stalin (Georgian), 21 January 1924 - 5 March 1953; Geogry Malenkov (Russian), 5 March 1953 - 8 February 1955; Nikita Khrushchev (Russian), 8 February 1955 14 October 1964 (deposed); Leonid Brezhnev (Ukrainian), 14 October 1964 - 10 November 1982; Yuri Andropov (Russian), 12 November 1982 - 9 February 1984; Konstantin Cherenkov (Russian), 13 February 1984 - 10 March 1985 and Mikhail Gorbachev (Russian), 11 March 1985 - 25 December 1991.

23 For a detailed examination of the origins and consequences of this, see Natasha Iliriani, "Some Manifestations of National Oppression in the Soviet Union Today", Unpublished Research Paper, No. 4, Socio-Political Studies, 1987 and Andreas Kappelee, "Ukraine and Russia: Legacies of the Imperial Past and Competing Memories", Journal of Eurasian Studies, Vol. 5, Issue 2, July 2014, pp. 107-115.

24 For a series of essays on the historical foundations and implications of Nigeria's 'national question', see Uyilawa Usuanlele and Bonny Ibhawoh (eds.), Minority Rights and National Question in Nigeria, New York: Palmgrave Macmillan, 2017.

25 Andreas Kappelee, “Ukraine and Russia: Legacies of the Imperial Past and Competing Memories”, p. 110.

26 Quoted from Natasha Iliriani "Some Manifestations of National Oppression in the Soviet Union Today", p. 4.

$27 \quad$ Ibid, pp. 5-7.

28 National Intelligence Council, “Dimensions of Civil Unrest in the Soviet Union”, CIA Historical Program, n.d., pp. 3-4. 29 Ibid, p. 3.

30 A.A. Zvorykin, "Cultural Policy in the Union of Soviet Socialist Republics", United Nations Educational, Scientific and Cultural Organization, 1970, pp. 9-64.

31 Bohdan Nahaylo, "Population Displacement in the former Soviet Union", UNHCR, Refugees Magazine, Issue 98, 1994, p. 7.

32 Ibid.

33 Sergey Markedonov, "Post-Soviet Russia: Torn Between Nationalism and Separatism", Russia in Global Affairs, No. 4, 27 December 2012.

34 Elizaveta Pokrovskaya, "The irreversible and absolute end of the era of Russian Empires", Euromaidan Press, 15 February 2015.

35 Celestine Bohlen, “The Union is Buried: What is Being Born”, The New York Times, 9 December 1991.

36 Quoted from "The End of the Soviet Union: Stanislau Shushkevich's Eyewitness Account" Demokratizatsiya retrieved from https://www2.gwu.edu/ ieresgwu/assets/docs/demokratizatsiya\%20archive/GWASHU_DEMO_21_3/T43 on 2 October 2017. Stanislav Shushkevich was a signatory to the Accords. Demokratizatsiya's unedited excerpt is the first English translation of Stanislav's autobiography, My Life: The Collapse and Resurrection of the USSR (pp. 315-338). The quotation to which this reference refers is on p. 329 of Stanislav's book.

37 Ibid, p. 332. 
38 Alexander Salenko, "Legal Aspects of the Dissolution of the Soviet Union in 1991 and Its Implications for the Reunification of Crimea with Russia in 2014" Max-Planck-Institut für ausländisches öffentliches Recht und Völkerrech, 2015, pp. 144-145.

39 Ibid, pp. 158-159.

40 Dina Newman, "How three men signed the USSR's death warrant”, BBC Magazine, 24 December 2016.

${ }^{41}$ Peter Rutland, "History in the Making: The Agreement That Ended the Soviet Union", The Moscow Times, 7 December 2016.

42 "The End of the Soviet Union: Stanislau Shushkevich's Eyewitness Account", p. 320

43 Quoted from Dina Newman, "How three men signed the USSR's death warrant".

44 See World Health Organisation, From Alma-Ata to the Year 2000: Reflections at the Midpoint Geneva: 1988. Particularly 'Declaration of Alma-Ata', pp. 7-10.

45 These were the Republics of Azerbaijani, Armenia, Byelorussia, Kazakhstan, Kirghizia, Moldavia, Tadzhikistan, Turk menia, Uzbekistan, Ukraine and the Russian Federation. Georgia joined the CIS in December 1993 and left in August 2009. However, the three Baltic States - Estonia, Latvia and Lithuania - whose independence had been earlier (6 September 1991) recognised by the Soviet Union did not participate.

46 Alma-Ata Declaration, p. 2.

47 The End of the Soviet Union: Text of Accords by Former Soviet Republics Setting Up a Commonwealth, The New York Times, 23 December 1991.

48 Quoted from Yehuda Z. Blum, "Russia Takes Over the Soviet Union's Seat at the United Nations”, European Journal of International Law, Vol. 3, 1992, p. 356.

49 Ibid.

50 For this kind of focus, see Yehuda Z. Blum, "Russia Takes Over the Soviet Union's Seat at the United Nations”, particularly the subsection titled 'Is Russia Entitled to the Soviet Permanent Seat in the UN Security Council?', p. 360; Jure Vidmar, Democratic Statehood in International Law: The Emergence of New States in Post-Cold War Practice, Oregon: Portland, 2013; Amos S. Hershey, “The Succession of States", American Journal of International Law, Vol. 5, No. 2, April 1911, pp. 285-297 and Alexander Salenko, "Legal Aspects of the Dissolution of the Soviet Union in 1991 and Its Implications for the Reunification of Crimea with Russia in 2014" Max-Planck-Institut für ausländisches öffentliches Recht und Völkerrech, 2015, pp. 144-145.

51 See, among others, United Nations Papers A/RES/46/241 - papers for the $3035^{\text {th }}$ meeting of 23 January $1992 ; 3041^{\text {st }}$ meeting of 29 January 1992; Security Council's Resolution 735 of 29 January 1992 and Plenary Papers for 31 July 1992: United Nations General Assembly 46/241, Forty-Sixth Session, 1992, p. 6.

52 Erik Castrén Institute of International Law and Human Rights, Finland edited by Jan Klabbers et. al. State Practice Regarding State Succession and Issues of Recognition/Pratique des étatsconcernant la succession d'éstats et les questions de reconnaissance, The Hague: Kluwer Law International, 1999, p. 54.

53 British Year Book of International Law, Vol. 63, 1992, p. 639.

54 State Practice Regarding State Succession and Issues of Recognition, p. 56.

55 Gromyko was a Belarusian. The others, all Russians, were Yakov Malik (1948-52); Valerian Zorin (1952-53; 1960-63); Andrey Vyshinsky (1953-54); Arkady Sobolev (1955-1960); Nicolai Fedorenko (1963-68); Yakov Malik (1968-76); Oleg Troyanovsky (1976-86); Yuri Dubinin (1986); Alexander Belonogov (1986-90) and Yuli Vorontsov (1990-91).

56 Yehuda Z. Blum, “Russia Takes Over the Soviet Union's Seat at the United Nations”, p. 355.

57 For example, at its $3006^{\text {th }}$ meeting of 10 July 1991, the UN Security Council referred the applications of some of the new republics to the Committee on the Admission of New Members 'for examination and report as provided in rule 59 of the provisional rules of procedure'. Subsequently, the Baltic States were admitted to the UN through Resolutions 709 (Estonia); 710 (Latvia) and 711 (Lithuania) of 12 September 1991. In the same vein, after fulfilling all procedural requirements, members of the CIS were admitted to the UN via the following Security Council Resolutions: 732 of 23 January 1992 (Kazakhstan); 735 (Armenia); 736 (Kyrgyzstan); 737 (Uzbekistan); and 738 (Tajikistan) of 29 January; 739 of 5 February (Moldavia); 741 of 7 February (Turkmenistan); 742 of 14 February (Azerbaijan); and 763 of 6 July (Georgia). United Nations Papers: Security Council Resolutions, 12 September 1991, pp. 48 \& 49 and Security Council Resolutions, 1992, pp. 110-116.

\section{References}

Anderson, David (1999). "The Collapse of Yugoslavia", Research Paper No. 14 1995-96, Parliamentary Research Service, 1995 CIA Historical Review Program “A Research Paper".

Barbara A. (1990). Anderson \& Brian D. Silver, "Growth and Diversity of the Population of the Soviet Union", Annals of the American Academy of Political science and Social Science, 510.

Blum Z. Yehuda (1992). "Russia Takes Over the Soviet Union's Seat at the United Nations", European Journal of International Law, Vol. 3.

British Year Book of International Law (1992). Vol. 63.

Bohlen, Celestine (1991). "The Union is Buried: What is Being Born”, The New York Times, 9 December. 
Burbank, Jane et. al. (eds) (2007). Russian Empire: Space, People, Power, 1700-1930, Indiana: Indiana University Press.

Cardinal B. Koziński (2014). "Historical Determinants of the Contemporary Polish - Russian Relations: Geographical and Nationalistic (Ethnic) Dimension”, Young Scientist, No. 9(12), September.

Conference Proceedings on "Crimes of the Communist Regimes" (2010). 24 \& 25 February, Senate Building, Prague, Czech Republic Prague.

Dumberry, Patrick (2007). State Succession to International Responsibility, Boston: Martinus Nijhoff Publishers.

Dostàl, Petr and Knippenberg, Hans (2013). 'The "Russification" of Ethnic Minorities in the USSR', Eurasian Geography and Economics, May.

Edmund, Walsh (1928). "The Fall of the Russian Empire: The End of the Monarchy", The Atlantic, February.

Exploring History (2016). "How Catherine the Great Annexed Crimea”, 11 January 2016.

Harris, Carolyn (2017). "The Abdication of Nicholas II Left Russia Without a Czar for the First Time in 300 Years", Smithsonian Magazine, 13 March, 2017, available at: http://www.smithonianmag. com/history-abdication-nicolas-ii-left-russia-without-tsar-first-time-300-years

Hershey S. Amos (1911). “The Succession of States", American Journal of International Law, Vol. 5, No. 2, April.

Iliriani, Natasha (1987). "Some Manifestations of National Oppression in the Soviet Union Today”, Unpublished Research Paper, No. 4, Socio-Political Studies.

Kappelee, Andreas (2014). "Ukraine and Russia: Legacies of the Imperial Past and Competing Memories", Journal of Eurasian Studies, Vol. 5, Issue 2, July.

Klabbers, Jan, et. al. (1999). State Practice Regarding State Succession and Issues of Recognition/ Pratique des étatsconcernant la succession d'éstats et les questions de reconnaissance, Erik Castrén Institute of International Law and Human Rights, The Hague: Kluwer Law International.

Lieven, Dominic (2016). Towards the Flame: Empire, War, and the End of Tsarist Russia, New York: Penguin Books.

Lorimer, Frank (1946). "The Population of the Soviet Union: History and Prospects", Economic, Financial and Transit Department, Geneva: League of Nations, National Intelligence Council, "Dimensions of Civil Unrest in the Soviet Union", CIA Historical Program, n.d.

Markedonov, Sergey (2012). "Post-Soviet Russia: Torn Between Nationalism and Separatism", Russia in Global Affairs, No. 4, 27 December.

Nahaylo, Bohdan (1994). "Population Displacement in the former Soviet Union", UNHCR, RefugeesMagazine, Issue 98.

Newman, Dina (2016). "How three men signed the USSR's death warrant", BBC Magazine, 24 December.

Pokrovskaya, Elizaveta (2015). "The irreversible and absolute end of the era of Russian Empires", Euromaidan Press, 15 February.

Prażmowska, Anita (2010). Poland. A Modern History London: I.B. Tauris.

Robinowitch, Alexander (2009). The Bolsheviks Come To Power New York: Haymarket Books.

Rutland, Peter (2016). "History in the Making: The Agreement That Ended the Soviet Union", The Moscow Times, 7 December. 
Salenko, Alexander (2015). "Legal Aspects of the Dissolution of the Soviet Union in 1991 and Its Implications for the Reunification of Crimea with Russia in 2014" Max-Planck-Institut für ausländisches öffentliches Recht und Völkerrech.

Schmitt, Bernadotte (2008). The Russian Revolution, Oxford: Oxford University Press, 2008.

Schwartz, Lee (2016). "A History of Russian and Soviet Censuses" in Ralph S. Clem (ed.), Research Guide to the Russian and Soviet Censuses, Ithaca: Cornel University Press.

Service, Robert (2017). The Last of the Tsars: Nicolas II and the Russian Revolution, London: Macmillan.

Stalin, J.V. (1922). "The Formation of the Union of the Soviet Republics", Speech Delivered at the First Congress of Soviets of the U.S.S.R, 30 December.

"The End of the Soviet Union: Stanislau Shushkevich's Eyewitness Account" Demokratizatsiya, available at: https://www2.gwu.edu/ ieresgwu/assets/docs/demokratizatsiya\%20archive/GWASHU_ DEMO_21_3/T43 on 2 October 2017

"The End of the Soviet Union: Text of Accords by Former Soviet Republics Setting Up a Commonwealth" (1991). The New York Times, 23 December.

"The Execution of Tsar Nicolas II, 1918", available at: http://www.eyewitnesstohistor.com/ nicolas.htm on 28 September 2017.

Tomkiw, Lydia (2016). "Russia-Ukraine Conflict: Two Years After Crimea Annexation", International Business Times, 19 March.

Trotsk, Leon (2008). History of the Russian Revolution, Chicago: Haymarket Books.

United Nations Papers - General Assembly: A/RES/46/241 and 1991 \& 1992 Security Council Resolutions.

Usuanlele, Uyilawa and Ibhawoh, Bonny (eds.) (2017). Minority Rights and National Question in Nigeria, New York: Palmgrave Macmillan.

Venturi, Franco (1960). Roots of Revolution, New York: Alfred A. Knopf.

Vidmar, Jure (2013). Democratic Statehood in International Law: The Emergence of New States in Post-Cold War Practice, Oregon: Portland.

Vienna Convention on Succession of States in Respect of Treaties (1978).

Weeks, R. (2010). Theodore "Russification/Sovietization”, European History Online, available at: http://leg-ego.eu/en/threads/models-and-stereotypes/russification-soviettization on 10 October 2017

World Health Organisation (1988). From Alma-Ata to the Year 2000: Reflections at the Midpoint Geneva.

Zvorykin, A.A. (1970). "Cultural Policy in the Union of Soviet Socialist Republics", United Nations Educational, Scientific and Cultural Organization. 


\title{
От «русификации» к «легализации»:
}

\section{Россия и вопрос о государстве - преемнике \\ Советского Союза}

\author{
Эммануэль Оладипо Ойджо \\ ${ }^{a}$ Государственный университет Экити \\ Нигерия, Адо-Экити, итат Экити \\ ${ }^{6}$ Сибирский федеральный университет \\ Россия, 660041, Красноярск, пр. Свободный, 79
}

\begin{abstract}
По некоторым якобы очевидным или давно забытым причинам Россия почти всегда упоминается как государство - преемник бывщего Союза Советских Социалистических Республик, СССР так же, как сам СССР был преемником ияарккой России. После Февральской революиии и отречения императора Николая II от престола 15 марта 1917 года династия Романовых, правившая более трехсот лет, была сброшена с престола. Точно так же после Октябрьской революиии и свержения Временного правительства под руководством Александра Керенского на территории несуществующей Российской империи были созданы четыре сочиалистические республики - это были Русская и Закавказская советские федеративные сочиалистические республики, а также Украинская и Белорусская советские соииалистические республики. 28 декабря 1922 года эти конституичонные республики создали СССР, и позже были созданы дополнительные союзные республики. СССР просуществовал семь десятилетий и распался в 1991 году, что привело к расчленению геополитического пространства на 15 государств. Ввиду некоторых, вероятно, достаточно ясных исторических и демографических факторов, а зачастую и просто «традиционного предположения» Российская Федераџия, созданная 25 декабря 1991 года, считается государством - преемником СССР. В данной статье представлено двоякое утверждение: первое, что Советский Союз «русифицировался» задолго до его распада и что «юридический» вид России в 1991 году был чистой формальностью и сменой терминологии с «русификации» на «легализащию»; и второе, что описание России как государствапреемника Советского Союза, хотя и популярное, ошибочно и на самом деле Россия является «государством - продолжателем», а не «государством - преемником» Советского Союза.
\end{abstract}

Ключевые слова: Россия, Российская империя, СССР, русификачия, револючия, население, республики.

Научная специальность: 07.00.00-исторические науки. 